\title{
The Regional Tax Policy: A Review in Greece
}

\author{
Nikolaos Varotsis ${ }^{1}$, Ioannis Katerelos ${ }^{2}$ \\ ${ }^{1}$ Tourism Management Department, Hellenic Open University, Patra, Greece \\ ${ }^{2}$ Psychology Department, Panteion-University, Athens, Greece \\ Email: varotsis.nikos@ac.eap.gr, iokat@panteion.gr
}

How to cite this paper: Varotsis, N. and Katerelos, I. (2019) The Regional Tax Policy: A Review in Greece. Modern Economy, 10, 1963-1983.

https://doi.org/10.4236/me.2019.108125

Received: June 27, 2019

Accepted: August 25, 2019

Published: August 28, 2019

Copyright $\odot 2019$ by author(s) and Scientific Research Publishing Inc. This work is licensed under the Creative Commons Attribution International License (CC BY 4.0).

http://creativecommons.org/licenses/by/4.0/

\begin{abstract}
The continuing ineffectiveness of the tax reforms in Greek economy raises concerns about the need for a meaningful restructuring of the structure of fiscal administration. Tax restructuring that enhances regional, local or European taxation by weakening government taxation can be a key factor in reforming the tax system. The degree of tax decentralization of the tax policy applied is likely to improve the fiscal order and management and, on the other hand, it can be strengthened tax revenues by enhancing tax compliance. The main purpose of this paper is to emphasize that the decentralization of taxation to a more socially acceptable regional fiscal policy can lead to an acceptable tax reform in the case of the Greek economy. A reform of the revenue management at local, regional, central and European level with a more socio-centric fiscal expenditure mix is more desirable.
\end{abstract}

\section{Keywords}

Regional Tax, Public Finance, Tax Policy, Tax Reform, Sociocentric, Decentralization

\section{Introduction}

The continuing ineffectiveness of the Greek tax system makes it necessary to seek a restructuring of the applied tax model. The constant changes in tax policy without the corresponding social consensus lead either to financial failures or to poor economic results due to over-taxation. Instead, a socially acceptable tax policy may promote tax compliance by cutting tax evasion.

A significant proportion of Greek society has created a firm belief [1] that tax laws are unfair and do not apply to everyone the same. This view largely stems from the inability of the public to discern at the right time those who attribute the legitimate taxes [2] but also those who escape tax evasion [3].

The main failure of the tax system in Greece is that it reproduces "tax evasion" 
and overdue debts of established taxes, distorting the real economy. Even continuous tax "reforms" have not stopped neither the continuous reproduction of tax evasion nor the continuous increase of non-taxable taxes.

Failure of the tax system is widening as new financial accounts are recorded. The continuous growth of overdue debts highlights the failures of the tax system, although the last ten years have been compounded by the constant changes in the legislative framework. The total collectability (timed payments) of income taxes, value-added tax, other indirect taxes and real estate single tax, other real estate taxes, at the end of 2017 amounted to $80.67 \%$. However, the total overdue debts at the end of 2018 exceed $€ 104.0$ billion [4], more than tripled in a decade of continuous tax reform while the total debtors go beyond four million.

There is a saturation of the tax capacity of the tax base of established taxes. In other words, taxable persons who are subject to tax gradually [5] become less able to respond to their payment. Modifications in the tax system do not increase the tax base, but instead appear to saturate the existing one. The continued production of overdue debts challenges the effectiveness of the existing tax system as well as lasting legislative changes, exacerbating fiscal apnea. Financial resources are exhausted by perpetuating a climate of uncertainty in the growth prospects of the real economy.

Economic cachexia is fueled by rising taxes that do not achieve tax equality by moving indirectly income from categories of taxpayers who can not conceal income (employees, pensioners, etc.) to other categories of taxpayers who persist in their delinquent behavior while retaining tax evasion at high levels approaching a quarter of GDP. In addition, economic apnea is maintained by the high indirect taxation that affects the inertia of economic activity [6], given that in Greece the value-added tax rate is the third highest among OECD countries, while it is widened by very high insurance contributions. The claim that high indirect taxation restrains economic model failures that aggravate current account performance coupled with high insurance contributions is contrasted by macroeconomic performance that does not create the appropriate growth conditions to improve the real economy.

Exploring the design of tax reform at governmental, regional and European level having incorporated social acceptance is an originality of this research. The research suggests a new approach to reforming a fiscal administration system at a regional level by studying the social consensus of such an attempt, analyzing and processing an anonymous questionnaire that was compiled online from a sample of the population responding positively to the request to participate. This methodology results in the presence of some limitations. The two main constraints are that the completion of an anonymous online questionnaire does not guarantee the absolute sincerity of responses, while the sample may include a small number of elderly or very busy taxpayers who tend to reject their participation more easily.

The paper is structured as follows: Section 2 describes the basic structure of the Greek tax system, the restructuring that has been implemented, the theoreti- 
cal framework of fiscal decentralization, in relation to a local tax revenue management system, the social consensus required in order to restructure the tax system and the positive impact on tax behavior of a tax system reform. Section 3 deals with the methodology used to collect and enrich the present survey, the sample involved in the survey as well as participants' statistics with regard to economic and social criteria. Section 4 presents and analyzes the results of tax decentralization and social consensus in a possible reform to a regional tax system and, the paper concludes with Sections 5 and 6 in which conclusions and reflections from the results of the survey are presented.

\section{Background}

\subsection{Applicable Tax Policy Mix}

Over the last ten years, a new model of tax policy has been formulated with a series of regulations. Since 2019, there have been significant changes in the implementation of tax legislation with a series of legislative provisions with more than a hundred tax law codification conversions followed by a number of circular interpretative directives which have completely revised the applicable tax policy [7]. The tax legislation reform of the tax model includes the new income Greek tax code [8], the new tax procedure code [9], the new real estate single tax and the implementation of the Greek accounting standards [10]. The main axes of the new tax reform are presented in Figure 1 below.

The main objectives of the new tax reform are to simplify the monitoring of financial transactions, the submission of taxpayers' declarations, the diversification of the imposition of penalties, the change in the control procedures and the enforcement of compulsory recovery measures. The new income tax code focuses, in conjunction with the legal framework for the prevention and suppression of money laundering [11], on identifying and taxing undeclared income, and in particular on income derived from illegal activities can not be legally justified (money laundering) or from unidentified sources of income. At the same time, it applies the mandatory application of market and real estate preservation documents. The new tax procedure code including sanctions differentiates the taxpayers' legal framework, while allowing for earlier tax cases, to be reconciled to a lower level. Also, with the changes in the audit process, the ability of the tax authority to interconnect through an electronic system of bank accounts and the implementation of a shorter process of automated seizure of bank accounts for taxpayers in public debts [12]. With the single property tax, a uniform property tax is imposed on almost all owners, while capital gains, large immovable property and real estate transfer taxes are retained. Changes have also been made to indirect taxation by enforcing value-added tax (VAT) rates, but also imposing a series of additional indirect taxes (fuel, food service, telephony, etc.).

The tax policy applied over the past five years is moving on three main axes. To the review (increase) in the taxation of income or property acquired, the determination of income not only from its sources but also from living costs and 


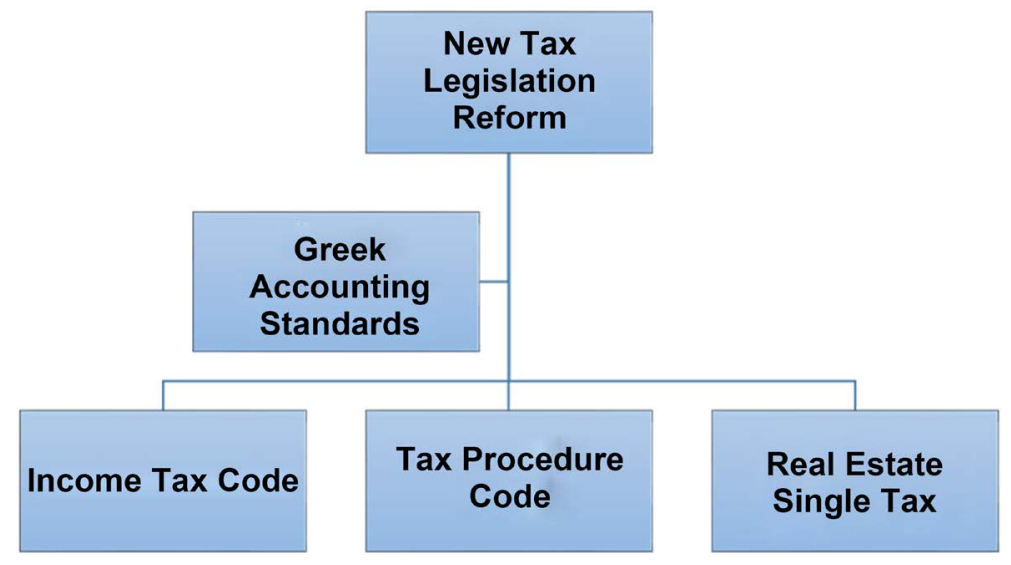

Figure 1. Basic legal framework of the tax model.

the additional burden of indirect taxation. The electronic archiving of all taxpayers' transactions has been established, without its practical implementation until now. Whilst apparently the tax mix applied tightens the taxpayer [13], it does not take into account a number of important features of a tax population dominated by high fatigue and aversion to the taxing authority due to the financial failures and injustices that have been caused to date.

It is clear that central (government) planning and management is maintained in all tax revenues without providing for an autonomous tax governance into regional and/or local level [14]. It does not integrate the cultural and social characteristics of the population to shape the new tax policy [15], insisting on the implementation of potentially successful prescriptions of other tax systems. Fiscal management remains independent of the formulation of the tax policy followed [16]. Social consensus remains unknown in implementing the new reforms that bring the new tax framework. Care has not been taken to remedy the injustices, the tax system has brought to the population to date (according to Independent Authority for Public Revenue's annual statistics in 2018, 90\% of the income taxes are paid by $19 \%$ of the population), but only blind horizontal expansions of the tax base. Moreover, no timetable has been provided for the modernization of all state bureaucracy procedures linked to an efficient economy in which the new tax framework will be applied. It is still unknown whether the information systems can perform all the cross-checks required to capture the financial transactions according to the total taxes paid and not simply to control their realization. However, the tax base has theoretically increased since the new tax reform provides for more taxes without having calculated the operating cost of the tax base elasticities [17] or adjusting to the new tax base.

\subsection{Local Government Finances}

Three are the main sources of local government revenue: income from taxation, grants and loans [18]. For the execution of works and the provision of services, municipalities impose taxes, fees, royalties and levies on their citizens, provided 
that they do not have the same tax authority but always act within the framework of a law which, identifies the persons liable, the subject to taxation, rates and exemptions. In this case, the receipt and collection of income are done by the municipalities themselves, as opposed to the central resources collected from the state and attributed to the local authorities. A disadvantage of local taxation is the creation of horizontal and vertical fiscal disparities and inequalities in the provision of public services and taxation of citizens.

The introduction of municipal taxes, fees, royalties and levies [19] is done by a formal law, which either imposes them automatically in favor of the first-degree municipalities (without the decision of the Municipal Council) or provides the possibility to the local authorities, to impose them by a decision of the City Council. In the latter case, enforcement is at the discretion of the City Council [20]. The fees are always imposed by a decision of the Municipal Council, which determines their rate.

There is still a difference in the two levels of government-central and local-from the consequences of tax evasion or the income elasticity of a tax, especially if the local government imposes only a small or a single tax. A substantial difference is observed in the economic operation of the two levels of administration. Central government functions more as a means of ensuring economic stability and redistribution of income, in relation to local government [21], do not have a correspondingly important role. Thus, a tax may seem more appropriate in terms of effectiveness and fiscal justice when applied centrally than at local level.

\subsection{Tax Decentralization}

Tax decentralization, is the extent to which the central government transfers a tax burden to a local authority [22], and is being valued by the percentage of tax revenues of local government in total public tax revenues or by comparing local government revenue with central government revenue. In this case nevertheless, the question arises as to the distinction between tax revenues belonging to the tax-collecting step and those belonging to that level, in favor of which they are charged by another level of administration.

A significantly higher degree of decentralization is found in the Nordic countries [23], and particularly in Denmark [24], where local government revenue reaches $81.46 \%$ of central government revenue. As shown in Figure 2 below, the structure of fiscal decentralization varies across Europe [25].

Figure 3 below shows the situation in the European states as regards the percentage structure of local government revenues. As shown in the table, Greece, Nederlands and Portugal secure the bulk of their revenue from non-tax revenues such as subsidies and borrowing.

In the European Union, the composition of budgetary resources has not changed over time. As can be seen from Figure 4, there is a slight increase in government intervention in central level [26]. 


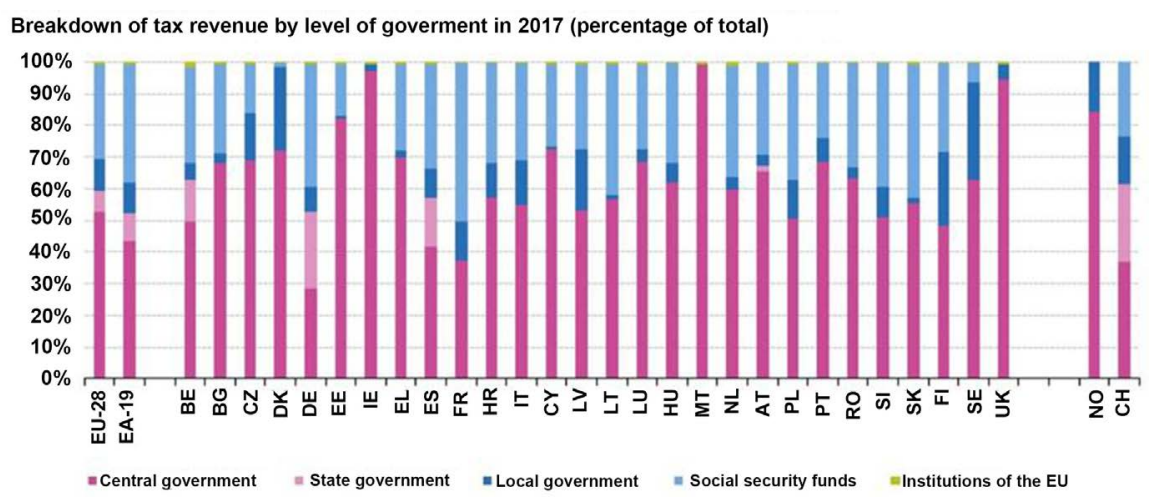

Figure 2. Breakdown of tax revenue by level in government in 2017. Source: Eurostat (2018).

Percentage revenue distribution to local government

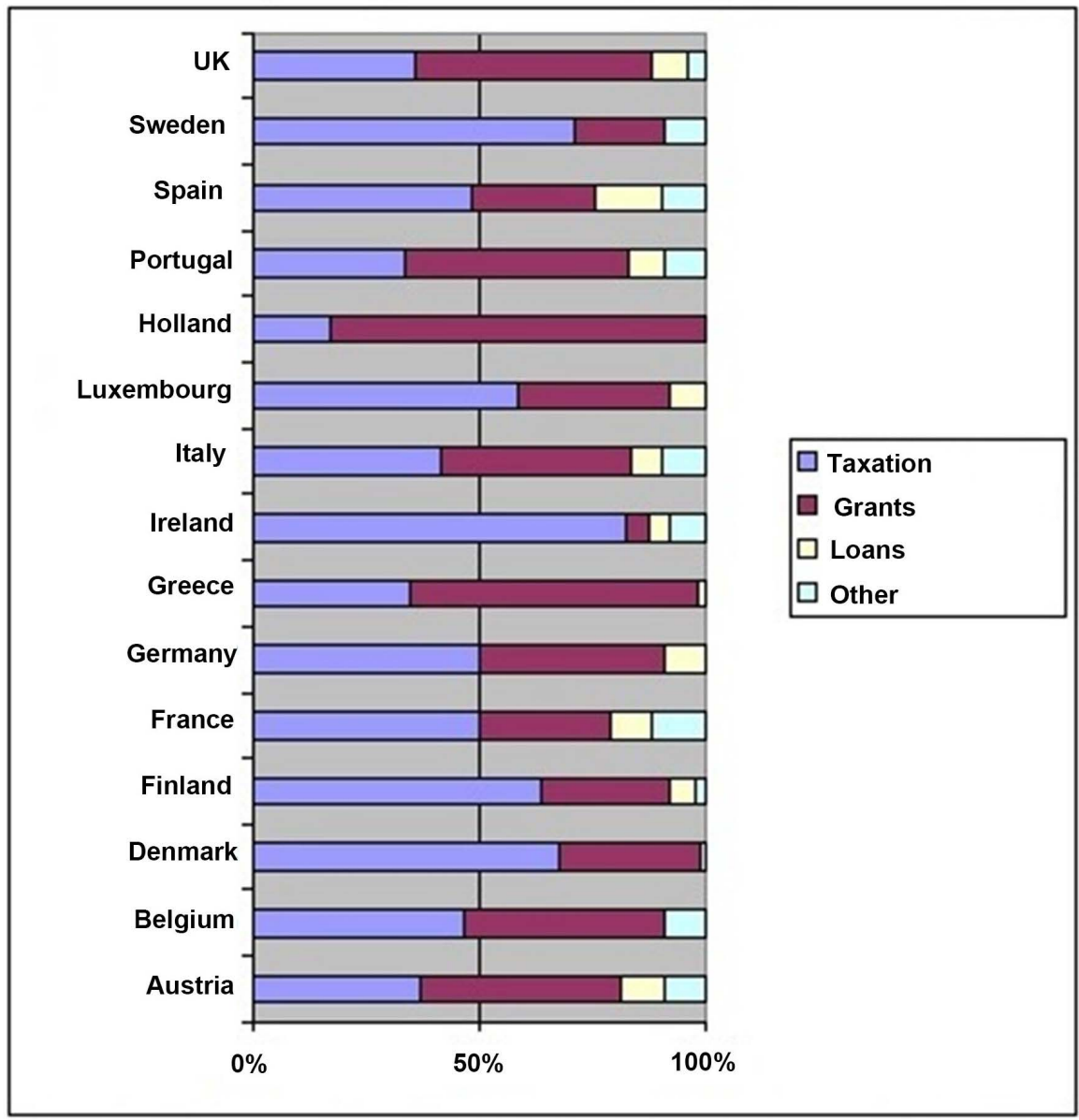

Figure 3. Percentage revenue distribution to local government. Source: European Commission (2017).

\subsection{Tax Behavior}

Individual tax behavior [27] often deviates from the rational model [28] to reward personal well-being. Individual behavior and decision-making [29] differ from rational selection by enhancing personal heuristics with cognitive 


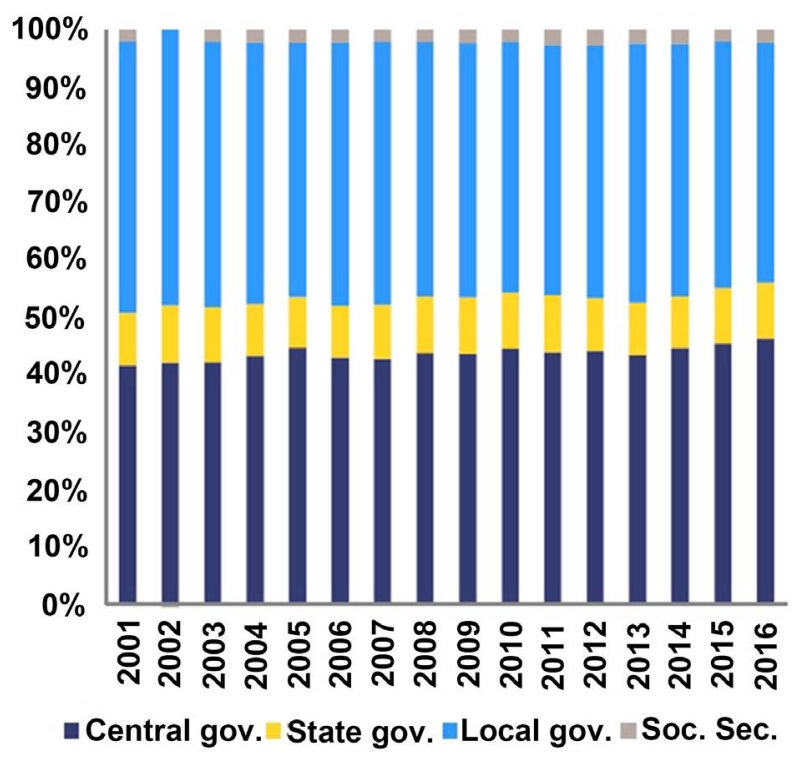

Figure 4. Percentage revenue distribution to central, state local level. Source: European Commission (2017).

constraints [30]. The sovereign characteristics of the taxpayer are to adopt rational self-esteem for personal material satisfaction. Tax evasion occurred alongside taxes [31] influenced by perceived justice in the tax system [32]. Compliance with tax rules is a priority for public finances and affects equality, efficiency and ultimately the impact of a tax system. When a significant proportion of the population can avoid or fail to systematically pay or not pay for the corresponding taxes, the tax system becomes unfair, punishing honest taxpayers by imposing additional necessary taxes.

On the other hand, the tax distorts the effectiveness of the tax system [33], exacerbating the welfare of taxpayers [34]. The imposition of increased tax rates and the ingenuity of taxing is too simple to achieve economic growth in a socio-economic system [35], may lead to a temporary increase in tax revenues, but using tax models with low social efficiency [36]. Maintaining a "marginal" behavior of the population with mixed strategies to temporarily respond to taxes, implies adjusting to a pattern of avoidance of taxes [37]. In addition, a taxation system of over-filing is fully exploited with unspecified effects on the real economy. Excessive taxation not only leads to tax exhaustion of the population, but also sparks social reactions for a so-called ineffective government. A tax system acceptable to the taxpayer is a prerequisite for an effective tax policy [38].

\subsection{Social Consensus}

Social consensus is an agreement for a commonly accepted social goal [39] by all parties involved [40]. The social consensus, also referred to as functionality, is based [41] on self-preservation and social responsibility societies [42], which are balanced by social acceptance in order to maintain the existing social order.

The social consensus contradicts [43] with conflict practice [44], which re- 
quires a modification of the existing social establishment in order to make changes. Social consensus aims to balance society through a commonly agreed agreement [45] on rules, values and operating rules in a specific context.

\subsection{Reform}

Tax reform is an indispensable component of state reform, a method [46] chosen by an elected government for fiscal improvement with a view to collecting taxes and the quality of public services. Reform is achieved by simplifying financial control, changing the progressivity of tax rates, imposing acceptable taxes, removing ineffective existing taxes, widening the tax base, and simplifying the collection of taxes [47]. The state reform aims at simplifying citizens' transactions with the state, improving the quality of government services, the functioning of public services [48] for the benefit of citizens [49] system [50] and the effectiveness of public works in terms of financial requirements and conditions.

The efficiency of the tax system and the effectiveness of the state contribute to the efficient management of the available financial resources and bring about economic growth. It is a key factor of economic prosperity, social cohesion and the basic survival element of an independent democratic state [51].

The effectiveness of the tax system depends on the economic environment as well as on the social characteristics of taxpayers [52]. The sustainability of a tax system consists of a fair distribution of the tax burden relative to actual income [53]. Pre-socialization of social justice against selfishness for taxation is the key factor for the effectiveness of a tax model [54]. A fair distribution of tax burdens is a precursor to the taxpayer's compromise with a consistent behavior towards his tax obligations, while stressing the importance of a fair tax system [55].

\section{Methodology}

\subsection{Participants}

The subject of the inquiry is Greek taxpayers. The quantitative survey was carried out on a sample of three hundred twenty questionnaires distributed, completed and collected online. All the data collected are the sample of quantitative research. A small sample of twenty-six questionnaires was used during the pre-screening process, which were distributed to each participant personally, followed by the evaluation for the development of the final form of the questionnaire and the method of completing them. The procedure was run across the period of a year and data were collected online through e-mail. All the participants were native Greek citizens submitting their tax returns in Greece.

\subsection{Procedure}

The data were systematically collected from the participants through e-mails. The method of online survey was chosen to conduct the research. The key features that helped in choosing the online survey method is the wide dispersion achieved in the research sample of the population with comparatively low cost, 
the large number of users of social networks, the confidential nature of online questionnaire completion, the easy-to-use process of completing the questionnaire and the possibility of online problem solving during the process.

Recordings of views and attitudes were made at the completion of the questionnaire. Data collection were conducted free Internet [56]using the online survey method [57]. This research was conducted using the questionnaire technique through online survey method, the collection of data began in the first half of year 2015 and was updated with enriched data from the second half of year 2018.

\subsection{Measures}

The overall sample of respondents consists of 320 anonymous questionnaires. A one-way analysis of variance was performed. The SPSS 20.0 verification process validated 320 true questionnaires. Multiple-character comparisons were performed using the LSD, Tukey, Bonferroni and Scheffe methods. The level of statistical significance was determined at 0.05 while a homogeneity test was performed. The number of participants includes 159 men (49.7\%) and 161 (50.3\%) women. The sample is random and according to individual characteristics mapping in Table 1, it is distributed throughout the Greek state territory. A higher participation rate of $45 \%$ comes from productive age (36 - 50), while large is the percentage of young people who represent $37 \%$ of the sample and the remaining $18 \%$ is older than 51 years. $13.4 \%$ are unemployed, $57.2 \%$ are employed in the private sector and $19.7 \%$ in the public sector.

The declared income of the participants is divided into $26.6 \%$ of those with an income of up to five thousand $€, 48.1 \%$ of those who claim income from six to twenty thousand $€, 21.9 \%$ of those who claim an income of twenty to fifty thousand $€$, and $3.4 \%$ of those reporting an income of more than fifty one thousand $€$. Of these, $24.4 \%$ have from up to five years of employment, $32.8 \%$ from six to fifteen years of employment, $36.3 \%$ from six to thirty years of employment, while the remaining $7.5 \%$ have more than thirty years of employment.

The level of education is shaped by $24.4 \%$ of secondary school graduates, $11.6 \%$ of those who have attended a technical school, $44.1 \%$ of those with tertiary education and $20.0 \%$ of researchers participating in postgraduate studies education level.

The individual and demographic characteristics of the sample are shown in Table 1.

\section{Results}

The questionnaire focused on the tax and fiscal policy mix. Participants were asked to propose a mix of tax and fiscal policy as well as a restructuring of the management of budgetary resources at three different levels (local, government, regional). In addition, they were asked to capture the fiscal policy mix that they perceive on the basis of their personal information. The recording was performed on a quota scale as a percentage in two or three levels. The 
Table 1. Individual characteristics of participants.

\begin{tabular}{|c|c|c|c|c|c|}
\hline \multicolumn{3}{|c|}{ Characteristics } & \multirow{2}{*}{$\begin{array}{c}\text { Participants } \\
120\end{array}$} & \multirow{2}{*}{$\begin{array}{c}\text { Percentages \% } \\
37.5\end{array}$} & \multirow{2}{*}{$\begin{array}{c}\text { Cumulative } \\
\text { Percentages } \\
37.5\end{array}$} \\
\hline \multirow{4}{*}{ Age } & \multirow{4}{*}{ Ages } & $18-35$ & & & \\
\hline & & $36-50$ & 147 & 45.0 & 83.40 \\
\hline & & $51-65$ & 52 & 16.3 & 99.70 \\
\hline & & 65 - above & 1 & 0.3 & 100.00 \\
\hline \multirow{4}{*}{$\begin{array}{c}\text { Family } \\
\text { Condition }\end{array}$} & \multirow{4}{*}{$\begin{array}{l}\text { Marital } \\
\text { Status }\end{array}$} & Single & 148 & 46.3 & 46.3 \\
\hline & & Married & 139 & 43.4 & 89.7 \\
\hline & & Widowed & 6 & 1.9 & 91.6 \\
\hline & & Divorced & 27 & 8.4 & 100.00 \\
\hline \multirow{4}{*}{$\begin{array}{c}\text { Permanent } \\
\text { Accommodation }\end{array}$} & \multirow{4}{*}{ Place } & Attiki & 152 & 47.5 & 47.5 \\
\hline & & N. Greece & 108 & 33.8 & 81.3 \\
\hline & & Islands & 21 & 6.6 & 87.8 \\
\hline & & Rest & 39 & 12.2 & 100.00 \\
\hline \multirow{4}{*}{ Profession } & \multirow{4}{*}{ Rating } & Employed & 198 & 61.9 & 61.9 \\
\hline & & Retired & 20 & 6.3 & 68.1 \\
\hline & & Rentier & 17 & 5.3 & 73.4 \\
\hline & & Practician & 85 & 26.6 & 100.00 \\
\hline \multirow{4}{*}{$\begin{array}{c}\text { Years of } \\
\text { Employment }\end{array}$} & \multirow{4}{*}{ Years } & $0-5$ & 75 & 23.4 & 23.4 \\
\hline & & $6-15$ & 105 & 32.8 & 56.3 \\
\hline & & $16-30$ & 116 & 36.3 & 92.5 \\
\hline & & 31 - above & 24 & 7.5 & 100.00 \\
\hline \multirow{4}{*}{ Education } & \multirow{4}{*}{ Level } & High School & 78 & 24.4 & 24.4 \\
\hline & & Technical school & 37 & 11.6 & 35.9 \\
\hline & & University & 141 & 44.1 & 80.0 \\
\hline & & Postgraduate & 64 & 20.0 & 100.00 \\
\hline \multirow{4}{*}{ Employment } & \multirow{4}{*}{ Sector } & Private & 183 & 57.2 & 57.2 \\
\hline & & Public & 63 & 19.7 & 76.9 \\
\hline & & Unemployment & 43 & 13.4 & 90.3 \\
\hline & & Other & 31 & 9.7 & 100.00 \\
\hline \multirow{4}{*}{$\begin{array}{l}\text { Tax (Declared) } \\
\text { Income }\end{array}$} & \multirow{4}{*}{ Stack (T. €) } & $0-5$ & 85 & 26.6 & 26.6 \\
\hline & & $6-20$ & 154 & 48.1 & 74.7 \\
\hline & & $21-50$ & 70 & 21.9 & 96.6 \\
\hline & & 51 - above & 11 & 3.4 & 100.00 \\
\hline \multicolumn{2}{|c|}{ Totals } & Total & 320 & 100.00 & \\
\hline
\end{tabular}


Figures 5-8 below show the percentages that taxpayers want to manage tax revenue initially in two (government and local) or three levels (government, regional/European and local).

In addition, the taxpayer was asked to answer what level of tax revenue management they trust most at three levels (central, European and local). The assessment of the solvency of tax revenues at three levels is recorded as follows.

From the governance table of the management of state resources, there appears to be a preference for management at central level and at least at local or even regional level. Between central and local, central is clearly preferred, while in a central, local and regional structure, it is preferred that the main structure be centralized, less local and even less regional.

Between central and European, there is a clear preference for government revenue to be managed at a central level than at European level since two out of three respondents roughly prefer the centralized tax revenue management. However, in terms of credibility in government revenue management, taxpayers appear to have more confidence in European management and less nearly equal to both central and local government. Mixed government revenue management at central, European and local level are acceptable.

On the contrary, taxpayers prefer a mixed level, where the management takes place more nationally than at the European level, while they trust more European management than any other level. There is a sense of fear of having more confidence in European budget management, even though they consider it more credible and trustworthy. From the further advanced statistical analysis, the

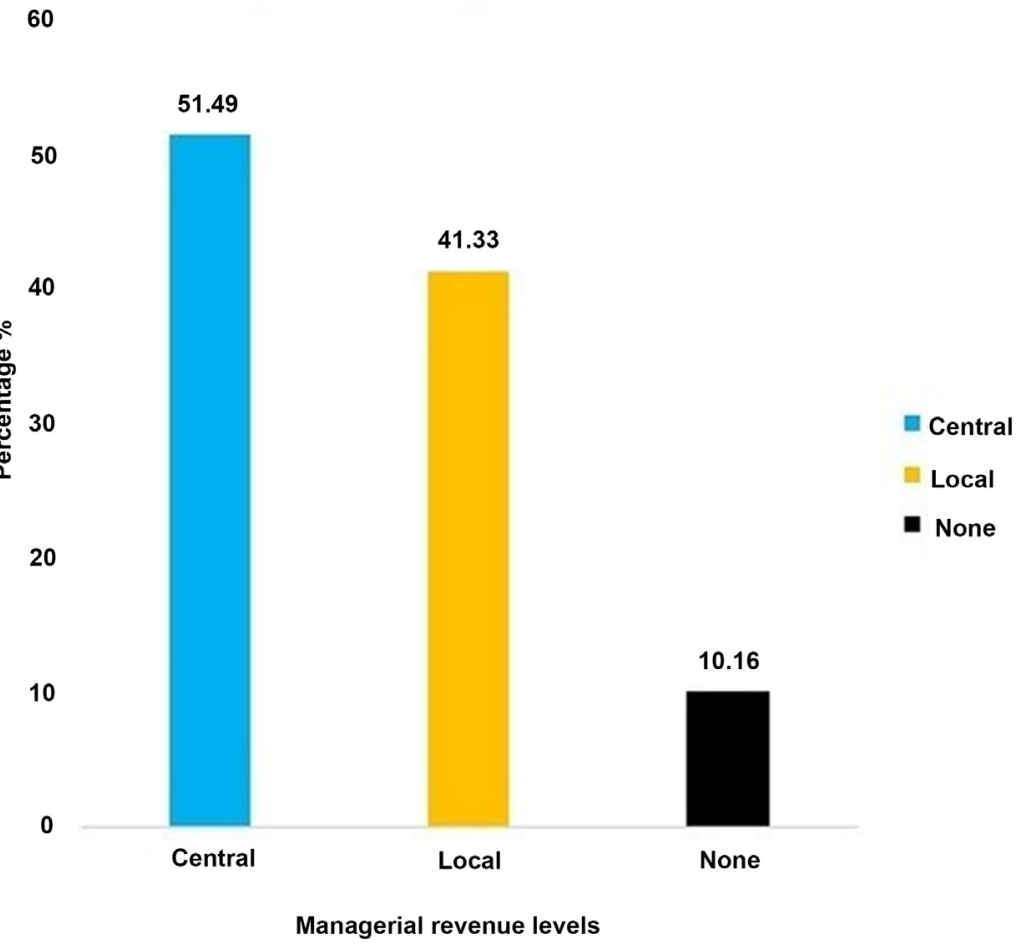

Figure 5. Managerial revenue management at two levels. 


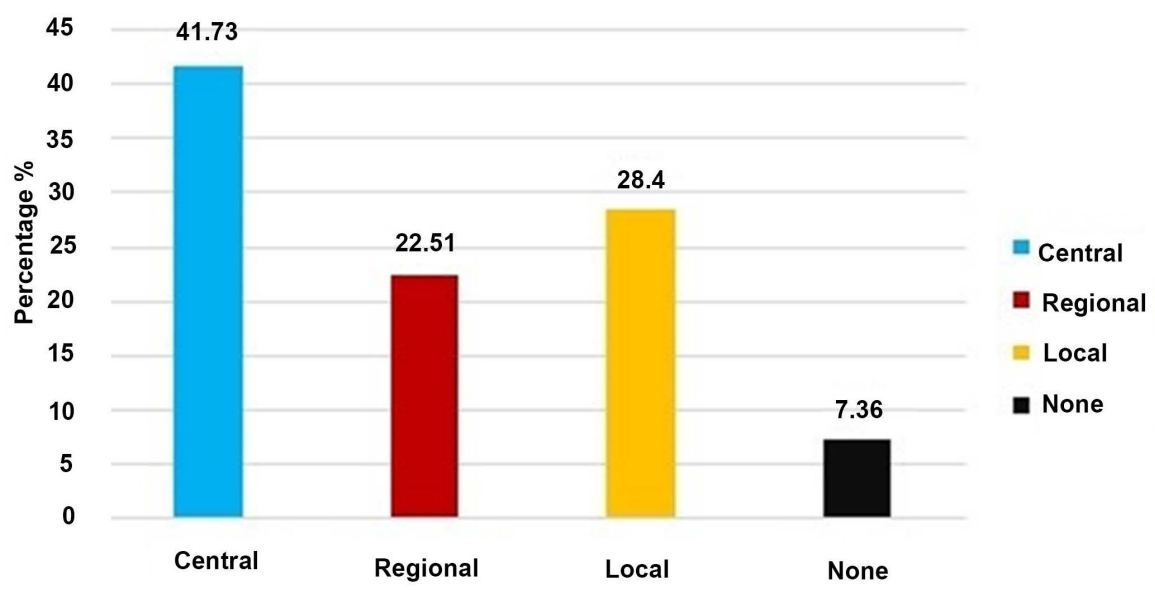

Managerial revenue levels

Figure 6. Managerial revenue management at three levels.

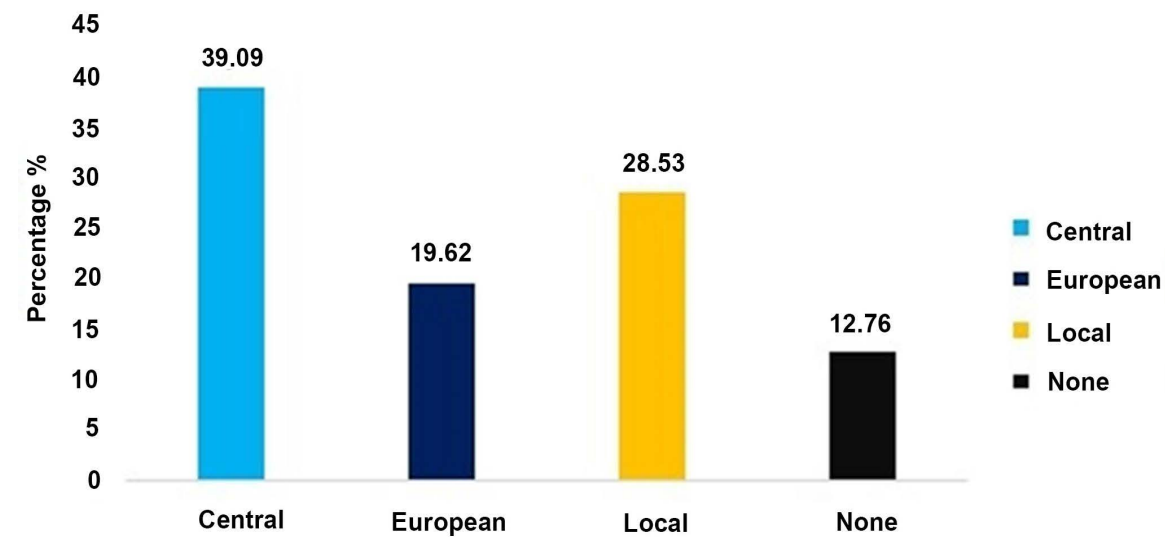

Managerial revenue levels

Figure 7. Managerial revenue management at three levels (European).

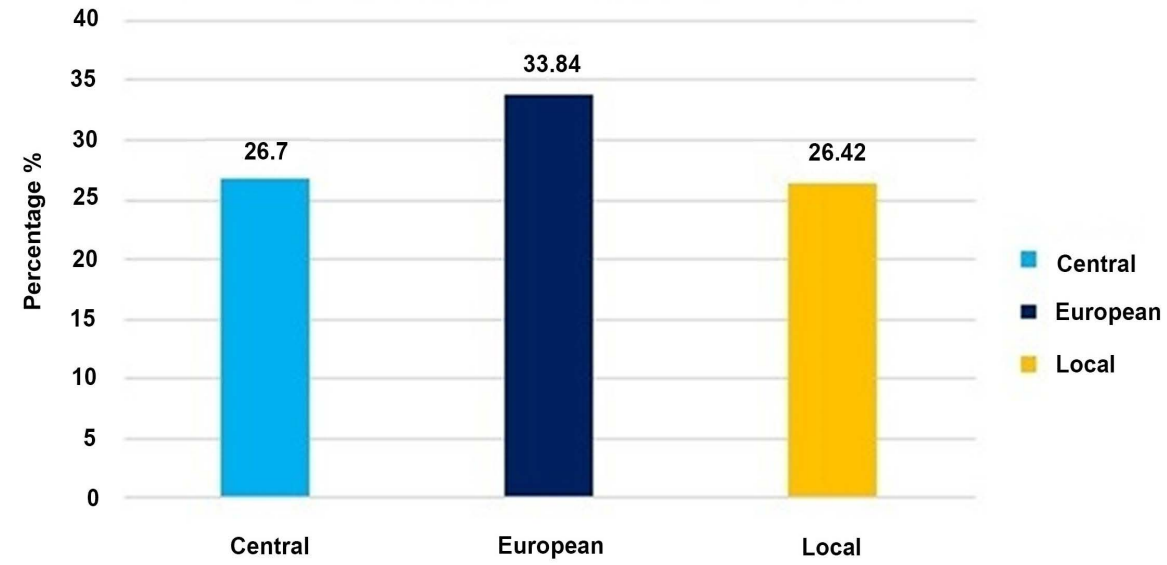

Managerial revenue levels

Figure 8. Trustfulness in managing tax revenue. 
following results were obtained that are statistically significant according to (p-value < 0.05) statistical significance of SPSS 20.0 and are listed in Figures 9-11. In Figure 9, it is listed willingness to managerial revenue management at two levels according to tax income $(€)$.

In Figure 10, it is listed willingness to managerial revenue management at two levels (central/local) according to employment of the participants.

The willingness to managerial revenue management at three levels (central/regional/local) according to employment of the participants is listed in Figure 11.

After being ensured a data suitability estimate for factor analysis [58], an exploratory factor analysis was conducted (principal component factoring) with varimax rotation (Kaizer normalization) using the software SPSS version 20.0. The analysis indicated 3 factors which were obtained with the SPSS 20.0 program.

Table 2 presents a summary of the factor analysis to the desired level of revenue management. The three factors identified in the analysis and assessment of a regional tax system were; local/regional, central and European. The factor lo$\mathrm{cal} /$ regional covers $44.53 \%$ of the prices, central covers $18.96 \%$ while European level covers $15.34 \%$ of the total prices collected.

Also, interestingly enough, the structure of the costs that taxpayers prefer as shown in Figure 12. Participants in the survey were invited to state the fiscal mix of spending they wished. The result of the survey is presented below in Figure 12.

From Figure 12, it appears that in reforming of budgetary expenditure, it is preferable to focus on spending on Health, Education, Social Security and Public Investment. In relation to existing state budget expenditures, there is a feeling that they are spent much more than taxpayers would like in the field of servicing

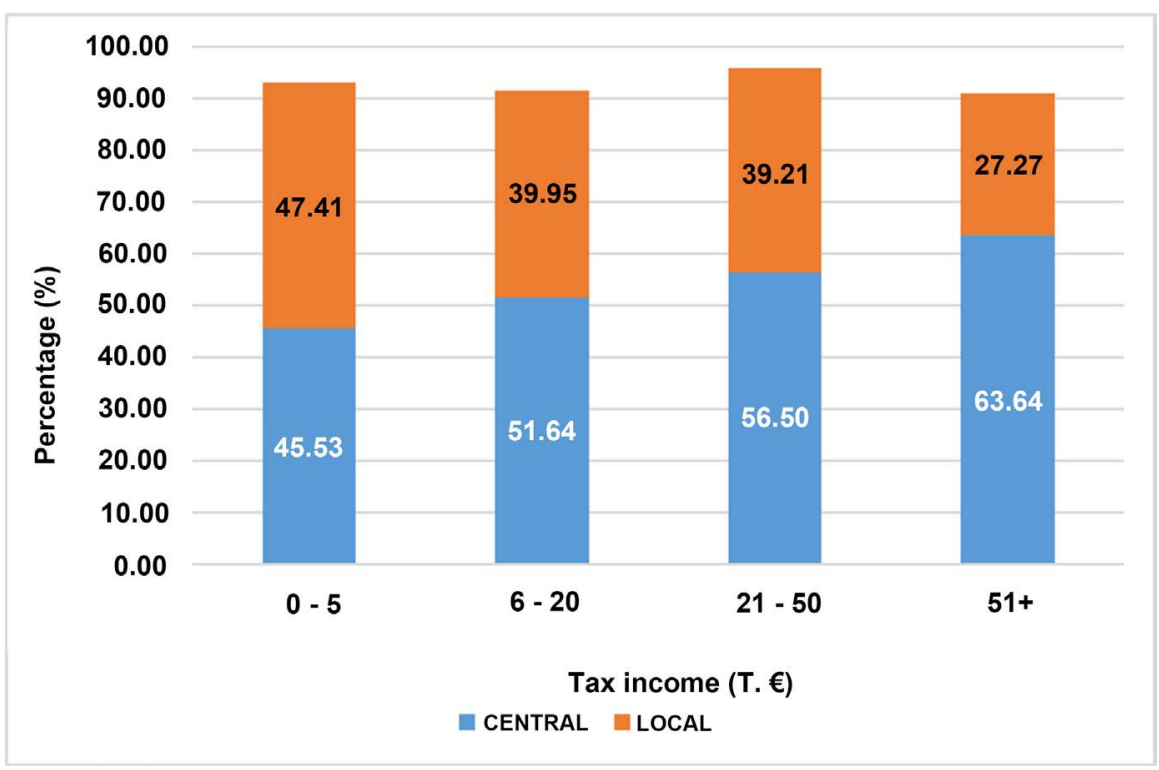

Figure 9. Managerial revenue management at two levels according to tax income $(\mathrm{p}<0.05)$. 


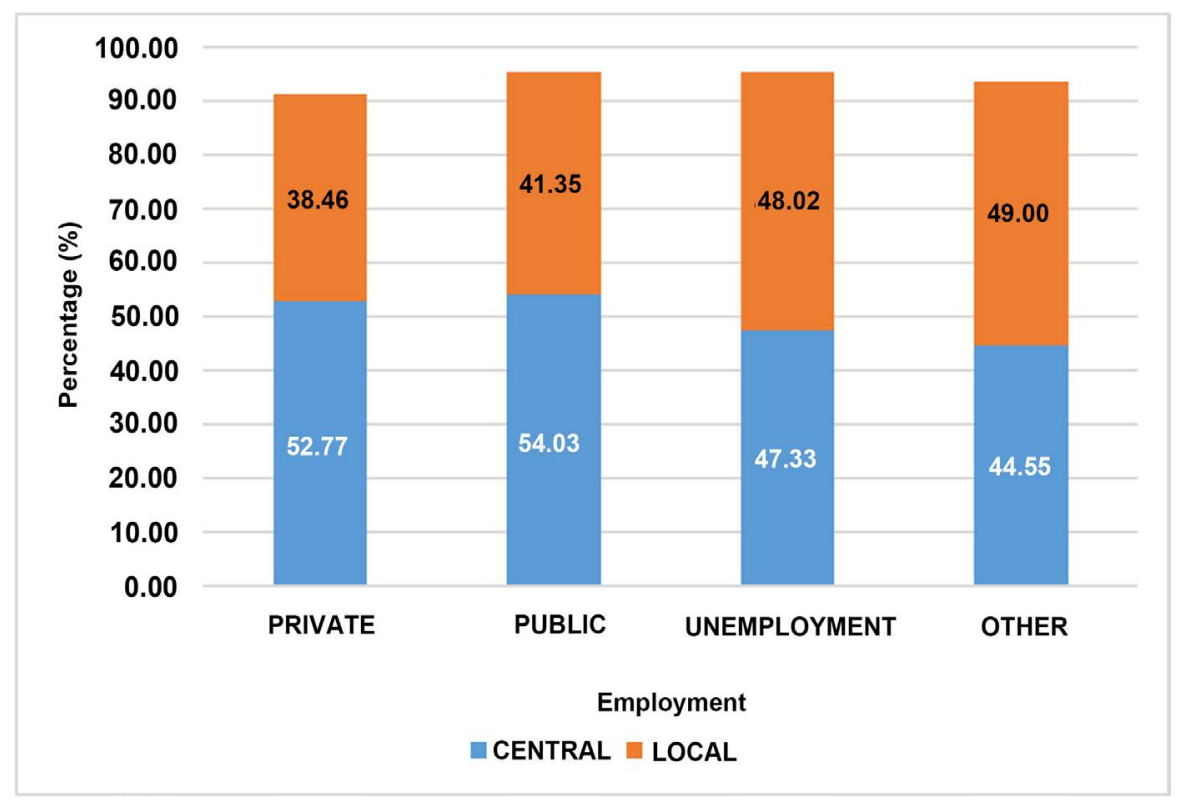

Figure 10. Managerial revenue management at two levels according to employment ( $\mathrm{p}<$ $0.05)$.

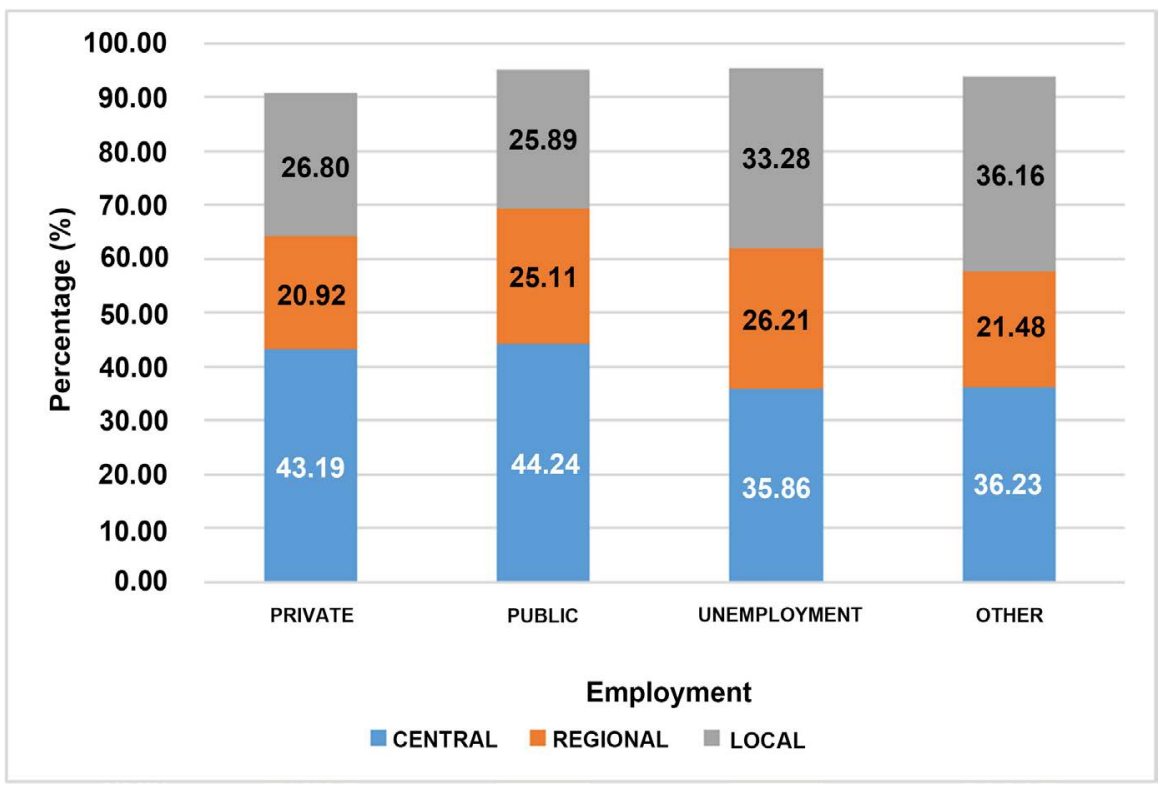

Figure 11. Managerial revenue management at three levels according to employment $(\mathrm{p}<$ $0.05)$.

public debt. Nevertheless is not confirmed by the apparently fewer actual state budget amounts being directed to the public debt. Characteristically, taxpayers have been reconciled with the existence of economic illegality, and accept shadow economy in the fiscal expenditure mix, while expecting it to be even less than what is actually recorded, specially in 2017 arose into 21.5\% [59].

Another exploratory factor analysis was conducted (principal component factoring) with varimax rotation (Kaizer normalization) using the software SPSS 


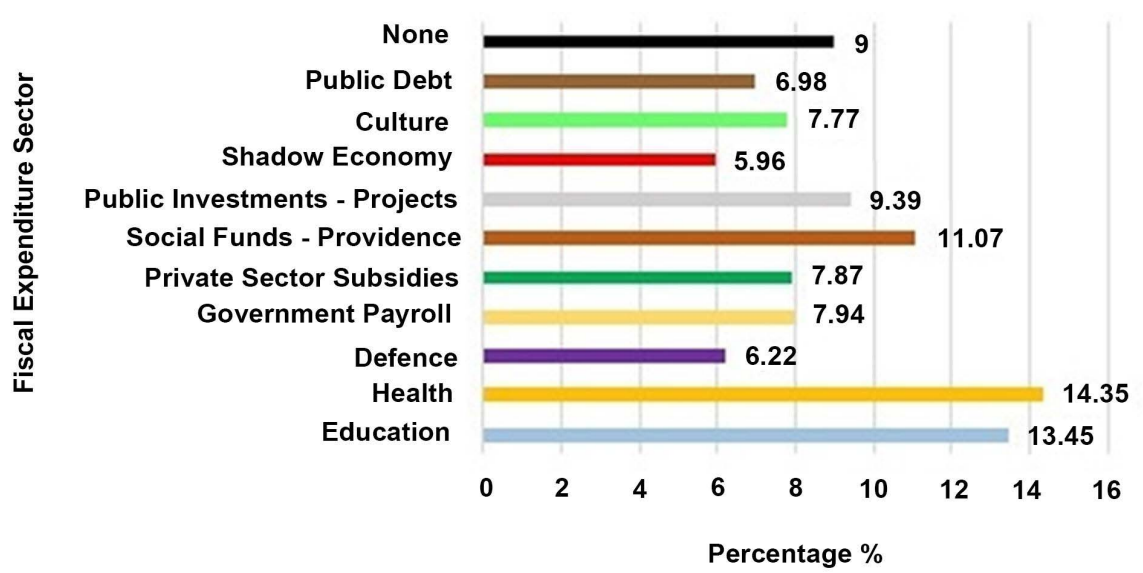

Figure 12. Structure of desired fiscal expenditure policy.

Table 2. Summary of factor analysis to the desired level of revenue management.

\begin{tabular}{cccc}
\hline & LOCAL/REGIONAL & CENTRAL & EUROPEAN \\
\hline LOCAL & 0.915 & & \\
LOCAL & 0.822 & & \\
LOCAL & 0.802 & & 0.515 \\
REGIONAL & 0.578 & & \\
CENTRAL & & 0.867 & \\
CENTRAL & & 0.848 & \\
CENTRAL & -0.389 & 0.823 & 0.922 \\
EUROPEAN & & & \\
\hline
\end{tabular}

Extraction Method: Principal Component Analysis, Rotation Method: Varimax with Kaiser Normalization. Rotation convereged in 6 ityerations.

version 20.0. The analysis indicated 2 factors which were obtained with the SPSS 20.0 program. Rotation converged in three iretations (Table 3 ).

The factor "Socialist" interprets $45.7 \%$ of the prices while and both of the factors-jointly with "Capitalist"-interpret $63.16 \%$ of total prices. The component plot in rotated space of the two factors is depicted in Figure 13.

\section{Discussion}

The effects of applying a tax model that reproduces increases in tax rates and arrears lead to periodic financial cachexia [60]. Unpredictable fiscal balances and weak positive increases in the sign of economic growth simply confirm the result of the failure to achieve a sound economic model that brings social prosperity, especially when after ten years of regular tax adaptation has been preceded by increasing taxation. The ten years of continued economic contraction of the Greek economy, while fiscal policy has changed radically and tax evasion has remained at just the same level, has simply confirmed not only the fragile economic structure but also the failure of the financial mix. The gradual consolidation of the banking system has not been reflected in the real economy, raising questions about the importance attributed to this factor in the Greek economy. 
Table 3. Summary of factor analysis to the desired fiscal expenditure mix.

\begin{tabular}{cccc}
\hline Fiscal Expenditure & variable code & \multicolumn{2}{c}{ FACTOR } \\
\hline & & SOCIALIST & CAPITALIST \\
\hline EDUCATION & Dim01 & 0.907 & \\
TRAINING & Dim02 & 0.880 & \\
HEALTH & Dim03 & 0.861 & \\
SOCIAL WELFARE-INSURANCE & Dim04 & 0.856 & 0.343 \\
AGRICULTURE-LIVESTOCK & Dim05 & 0.768 & \\
CULTURE & Dim06 & 0.729 & 0.449 \\
TOURISM & Dim07 & 0.653 & 0.388 \\
PUBLIC WORKS & Dim08 & 0.535 & 0.760 \\
SHIPPING & Dim09 & & 0.667 \\
DEFENCE & Dim10 & -0.405 & 0.549 \\
INDUSTRY & Dim11 & 0.502 & 0.472 \\
ATLETICS & Dim12 & & \\
\hline
\end{tabular}

Extraction Method: Principal Component Analysis, Rotation Method: Varimax with Kaiser Normalization.

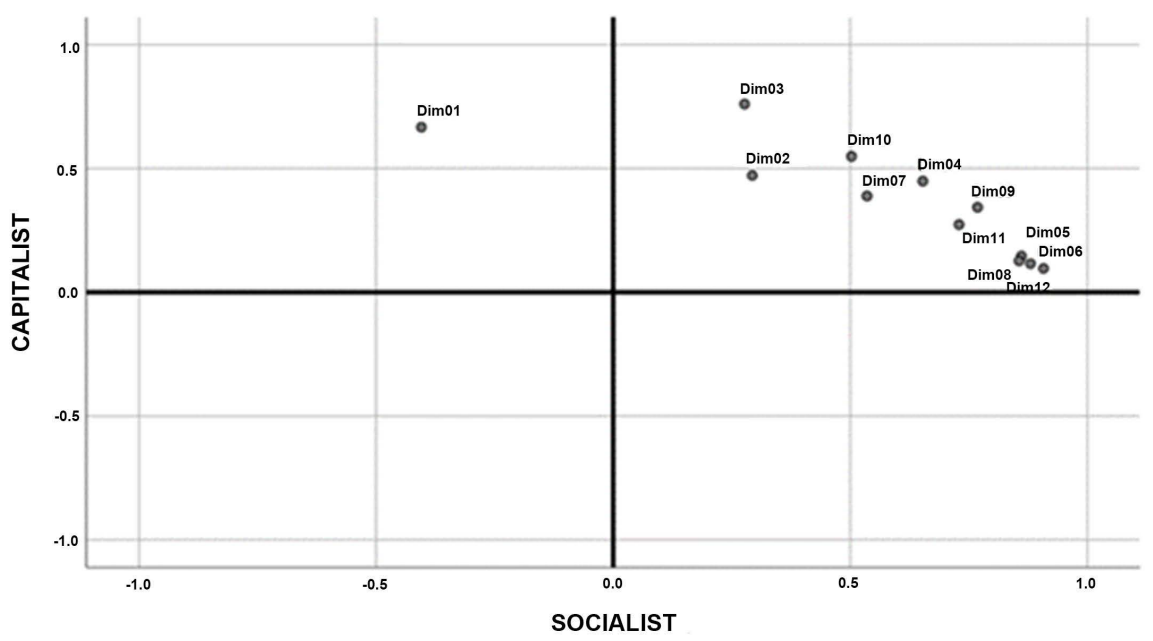

Figure 13. Component plot in rotated space.

Restructuring the tax model [61] is imperative for the growth of the Greek economy. The implementation of cyber-centric management models and tax revenues, apart from failing in fiscal management leading to the Greek economy's bankruptcy, maintain an unprecedented centralized management without positive results in the Greek economy. The dependence of local actors on a government-centered budget management over time makes it harder to improve their finances. Disengagement of local actors from the state budget can improve public finances by helping to manage transparency and fiscal reform.

The key factors in the reforming of the tax system as arose from factorial analysis being summarized in local/regional (peripheral), central and European 
levels of public revenue management. Two significant highlights are the strong desire for more local/regional fiscal revenue management, contrary to the current cyber-centric way of managing public revenue, and on the other hand the acceptance of a significant percentage of fiscal management at European level.

The choice of the fiscal model that will allocate tax decentralization needs further study. Important elements that need to be thoroughly investigated are the tax sector to be followed by fiscal decentralization (direct taxation, indirect taxation, real estate), the transparency of their management by local authorities, the degree of centralized management control, autonomy of local policy budgets, legal compliance status of taxpayers' response. In any case, one of the key points of tax absorption is the extent to which tax revenue is consistent with the tax and public autonomy of local authorities.

The factor analysis of the desired fiscal expenditure mix has highlighted two factors in which the participants are depicted as "Socialist" and "Capitalist" (investment-centric). Nearly half of the sample-almost $45.7 \%$-wishes a more sociocentric fiscal budget aimed at strengthening the welfare state and mild growth (education, health, tourism, public services), while there is also a significant percentage approaching $17.46 \%$ prefering a more focused fiscal budget based on shipping, industry, public investment and athletic industry. This finding raises a meditation if the fiscal expenditure mix needs to be driven mainly by socio-economic budget costs [62], limiting investment-centric expenditure [63] that can be possibly left freely in the macroeconomic mix at private expenditure.

Institutionalization as well as the legal defense of fiscal decentralization is one of the major steps towards achieving the reform. In order to achieve maximum compliance by the taxpayer, transparency and fairness can be legally ensured by local resource management bodies. A fiscal planning model that incorporates fiscal, socio-psychological and decentralizing elements is likely to contribute to fiscal restructuring, shrinking the shadow economy and contributing to tax compliance.

\section{Conclusions}

The radical reforming of the tax system is extremely demanding both in terms of management and in the direction of budgetary fiscal expenditure. Primarilly, there appears to be a predominance of management at local or regional level rather than at central or European level. In managing state resources at central, local and regional level, it is preferred that the main structure should be implemented at local, less regional or/and central level. Instead, there is a clear preference for government revenue to be centrally managed between the central and the European level.

Nevertheless, at a level of credibility in government revenue management, taxpayers appear to have more confidence in European management and less nearly equally both central and local management. However, there is an agreement on a mixed government revenue management at central, European and 
local/regional level with a more acceptable preference for the last one.

It is opposed that taxpayers prefer a mixed level whereupon the management is more central or local/regional than European level, while they trust more European management than any other level. There is a sense of worrying of having more confidence in European budget management, even though they consider it to be more credible and reliable level of management. The higher the income of participating taxpayers, the less they prefer local/regional financial management. Employees in the public and private sectors are more likely to prefer centralized level tax revenue management than at local/regional level in relation to unemployed, retired and other freelancers.

It is accepted that there is a need for a radical reformation of the public revenue management and the fiscal expenditure mix. A more socio-economic and socio-centric mix of fiscal expenditure is preferable to a more investment-friendly mix. The acceptable level of public revenue management is probably more lo$\mathrm{cal} /$ regional than central/governmental, but a mixed management of public revenue at local/regional, central and European level is also acceptable.

\section{Conflicts of Interest}

The authors declare no conflicts of interest regarding the publication of this paper.

\section{References}

[1] Gainous, J., Martinez, M.D. and Craig, S.C. (2010) The Multiple Causes of Citizen Ambivalence: Attitudes about Social Welfare Policy. Journal of Elections, Public Opinion and Parties, 20, 335-356. https://doi.org/10.1080/17457289.2010.490717

[2] Robbins, B. and Kiser, E. (2018) Legitimate Authorities and Rational Taxpayers: An Investigation of Voluntary Compliance and Method Effects in a Survey Experiment of Income Tax Evasion. Rationality and Society, 1-55. https://doi.org/10.2139/ssrn.2913071

[3] Slemrod, J. (2007) Cheating Ourselves: The Economics of Tax Evasion. Journal of Economic Perspectives, 21, 25-48. https://doi.org/10.1257/jep.21.1.25

[4] IAPR (2019) At EUR 104.652 Billion in February 2019, the Outstanding Debt to the Public. Independent Authority for Public Revenue (IAPR) Press, Athens.

[5] Young, H.P. (1990) Progressive Taxation and Equal Sacrifice. The American Economic Review, 80, 253-266.

[6] Katsimi, M. and Moutos, T. (2010) EMU and the Greek Crisis: The Political-Economy Perspective. European Journal of Political Economy, 24, 568-576.

https://doi.org/10.1016/j.ejpoleco.2010.08.002

[7] Naftemporiki (2017) Tax Instability with 106 Laws. https://www.naftemporiki.gr/finance/story/1294750/forologiki-astatheia-me-106-no $\underline{\text { mous }}$

[8] Greek Tax Code (2013) Tax Income. Law, 4172/2013. A 167/13. The National Printing House, Athens, 2457-2516.

[9] Greek Tax Code (2013) Tax Procedures. Law, 4174/2013. A 170/13. The National Printing House, Athens, 2533-2556.

[10] Greek Tax Code (2014) Greek Accounting Standards. Law, 4308/2014. A 251/14. 
The National Printing House, Athens, 7651-7746.

[11] Greek Tax Code (2008) Prevent and Suppress Money Laundering, Criminal Activities and the Financing of Terrorism. Law, 3691/2008. A 166/08. The National Printing House, Athens, 3129-3160.

[12] O’Neill, B., Sorhaindo, B., Xiao, J.J. and Garman, T.E. (2005) Financially Distressed Consumers: Their Financial Practices, Financial Well-Being, and Health. Financial Counseling and Planning, 16, 73-87.

[13] Alogoskoufis, G. (2019) Greece and the Euro: A Mundellian Tragedy. CGK Working Paper No. 1, 1-78.

[14] Porter, M.E. (1996) Competitive Advantage, Agglomeration, Economies, and Regional Policy. International Regional Science Review, 19, 85-90. https://doi.org/10.1177/016001769601900208

[15] Nantell, S.C. (1999) A Cultural Perspective on American Tax Policy. Chapman Law Review, 2, 33-93.

[16] McMillan, J. and Woodruff, C. (2002) The Central Role of Entrepreneurs in Transition Economies. Journal of Economic Perspectives, 16, 153-170. https://doi.org/10.1257/089533002760278767

[17] Bruce, D., Fox, W.F. and Tuttle, M.H. (2006) Tax Base Elasticities: A Multi-State Analysis of Long-Run and Short-Run Dynamics. Southern Economic Journal, 73, 315-341. https://doi.org/10.2307/20111894

[18] Easterly, W. and Rebelo, S. (1993) Fiscal Policy and Economic Growth: An Empirical Investigation. National Bureau of Economic Research Working Paper No. 4499, 1-57. https://doi.org/10.3386/w4499

[19] Heymans, C. (2006) Local Government Organization and Finance: South Africa. In: Shah, A., Ed., Local Governance in Developing Countries, The World Bank, Washington DC, 47-92.

[20] Braithwaite, J., Walker, J. and Grabosky, P. (1987) An Enforcement Taxonomy of Regulatory Agencies. Law and Policy, 9, 323-350.

https://doi.org/10.1111/j.1467-9930.1987.tb00414.x

[21] Weingast, B.R. (1995) The Economic Role of Political Institutions: Market-Preserving Federalism and Economic Development. The Journal of Law, Economics and Organization, 11, 1-31.

[22] Davulis, G., Peleckis, K. and Slavinskaite, N. (2013) Development of Local Municipality Taxes and Principles of Fiscal Policy in Lithuaia. American International Journal of Contemporary Research, 3, 38-50.

[23] Tossebro, J., Bonfils, I.S., Teittinen, A. Tideman, M., Traustadottir, R. and Vesala, H. (2012) Normalization Fifty Years beyond-Current Trends in Nordic Countries. Journal of Policy and Practice in Intellectual Disabilities, 9, 134-146. https://doi.org/10.1111/j.1741-1130.2012.00340.x

[24] Iversen, T. (1996) Power, Flexibility, and the Breakdown of Centralized Wage Bargaining: Denmark and Sweden in Comparative Perspective. Comparative Politics, 28, 399-436. https://doi.org/10.2307/422051

[25] Eurostat (2018) Tax Revenue Statistics. Eurostat, Brussels.

[26] European Commission (2017) Report in Public Finance in EMU. European Commission, Brussels.

[27] Katerelos, I. and Varotsis, N. (2017) A Cusp Catastrophe Model of Tax Behavior. Nonlinear Dynamics, Psychology, and Life Sciences, 21, 89-112.

[28] Conlisk, J. (1996) Why Bounded Rationality? Journal of Economic Literature, 34, 
$669-700$

[29] Edwards, W. (1954) The Theory of Decision Making. Psychological Bulletin, 51, 380-417. https://doi.org/10.1037/h0053870

[30] Tversky, A. and Kahneman, D. (1974) Judgment under Uncertainty: Heuristics and Biases. Science, 185, 1124-1131. https://doi.org/10.1126/science.185.4157.1124

[31] Kirchler, E., Hoelzl, E. and Wahl, I. (2008) Enforced versus Voluntary Tax Compliance: The "Slippery Slope" Framework. Journal of Economic Psychology, 29, 210-225. https://doi.org/10.1016/j.joep.2007.05.004

[32] Andreoni, J., Erard, B. and Feinstein, J. (1998) Tax Compliance. Journal of Economic Literature, 36, 818-860.

[33] Kaplow, L. (1996) How Tax Complexity and Enforcement Affect the Equity and Efficiency of the Income Tax. National Tax Journal, 49, 135-150.

[34] Cullis, J.G. and Lewis, A. (1997) Why People Pay Taxes: From a Conventional Economic Model to a Model of Social Convention. Journal of Economic Psychology, 18, 305-321. https://doi.org/10.1016/S0167-4870(97)00010-X

[35] Murphy, K. (2008) Enforcing Tax Compliance: To Punish or Persuade? Economic Analysis and Policy, 38, 113-135. https://doi.org/10.1016/S0313-5926(08)50009-9

[36] Wenzel, M. (2004) An Analysis of Norm Processes in Tax Compliance. Journal of Economic Psychology, 25, 213-228. https://doi.org/10.1016/S0167-4870(02)00168-X

[37] Meder, Z.Z., Simonovits, A. and Vincze, J. (2012) Tax Morale and Tax Evasion: Social Preferences and Bounded Rationality. Economic Analysis and Policy, 42, 171-188. https://doi.org/10.1016/S0313-5926(12)50019-6

[38] Laffer, A.B. (2004) The Laffer Curve: Past, Present and Future. Publication No. 1765. The Heritage Foundation, Washington DC.

https://www.heritage.org/taxes/report/the-laffer-curve-past-present-and-future

[39] Wood, J.V. (1989) Theory and Research Concerning Social Comparisons of Personal Attributes. Psychological Bulletin, 106, 231-248. https://doi.org/10.1037/0033-2909.106.2.231

[40] Weller, S.C. (2007) Cultural Consensus Theory: Applications and Frequently Asked Questions. Field Methods, 19, 339-368. https://doi.org/10.1177/1525822X07303502

[41] Keltner, D. and Kring, A.M. (1998) Emotion, Social Function and Psychopathology. Review of General Psychology, 2, 320-342. https://doi.org/10.1037/1089-2680.2.3.320

[42] Sutinen, J.G. and Kuperan, K. (1999) A Socio-Economic Theory of Regulatory Compliance. Journal of Social Economics, 26, 174-193. https://doi.org/10.1108/03068299910229569

[43] Ross, L., Greene, D. and House, P. (1976) The "False Consensus Effect": An Egocentric Bias in Social Perception and Attribution Processes. Journal of Experimental Social Psychology, 13, 279-301. https://doi.org/10.1016/0022-1031(77)90049-X

[44] Lane, W.C. (1976) Consensus, Conflict, and International Stratification Theories of Modernization: An Evaluation. Mid-American Review of Sociology, 1, 19-32. https://doi.org/10.17161/STR.1808.4796

[45] Peredo, A.M. and McLean, M. (2006) Social Entrepreneurship: A Critical Review of the Concept. Journal of World Business, 41, 56-65. https://doi.org/10.1016/j.jwb.2005.10.007

[46] Organization for Economic Co-Operation and Development (OECD) (2010) Citizen-State Relations: Improving Governance through Tax Reform. TPA, OECD, Paris. 
[47] Slemrod, J. (2001) A General Model of the Behavioral Response to Taxation. International Tax and Public Finance, 8, 119-128. https://doi.org/10.1023/A:1011204301325

[48] Matei, L. and Lazar, C.G. (2011) Quality Management and the Reform of Public Administration in Several States in South-Eastern Europe. Comparative Analysis. Theoretical and Applied Economics, 18, 65-98.

[49] Allan, J.P. and Scruggs, L. (2004) Political Partisanships and Welfare State Reform in Advanced Industrial Societies. American Journal of Political Science, 48, 496-512. https://doi.org/10.1111/j.0092-5853.2004.00083.x

[50] Perez, S.A. and Westrup, J. (2010) Finance and the Macroeconomy: The Politics of Regulatory Reform in Europe. Journal of European Public Policy, 17, 1171-1192. https://doi.org/10.1080/13501763.2010.513568

[51] Anderson, K.M. (2001) The Politics of Retrenchment in a Social Democratic Welfare State. Comparative Political Studies, 34, 1063-1091. https://doi.org/10.1177/0010414001034009005

[52] Varotsis, N. and Katerelos, I. (2018) Models of Tax Planning Simulation: The Case of Greece. Open Journal of Modelling and Simulation, 6, 27-44. https://doi.org/10.4236/ojmsi.2018.63003

[53] Van Dijke, M. and Verboon, P. (2010) Trust in Authorities as a Boundary Condition to Procedural Fairness Effects on Tax Compliance. Journal of Economic Psychology, 31, 80-91. https://doi.org/10.1016/j.joep.2009.10.005

[54] Fehr, E. and Schmidt, K.M. (1999) A Theory of Fairness, Competition and Cooperation. The Quarterly Journal of Economics, 114, 817-868. https://doi.org/10.1162/003355399556151

[55] Barth, E., Cappelen, A.W. and Ogendal, T. (2013) Fair Tax Evasion. Nordic Journal of Political Economy, 38, 1-16. https://doi.org/10.2139/ssrn.2262192

[56] Bryman, A. (2012) Social Research Methods. 4th Edition, Oxford University Press, Oxford, 653-681.

[57] Reips, U.-D. (2002) Standards for Internet-Based Experimenting. Experimental Psychology, 49, 243-256.

[58] Brace, N., Kemp, R. and Snelgar, R. (2018) SPSS for Psychologists. Red Globe Press Macmillan International, London.

[59] Medina, L. and Schneider, F. (2018) Shadow Economies around the World: What Did We Learn over the Last 20 Years? IMF Working Paper, WP/18/17, 1-76. https://doi.org/10.5089/9781484338636.001

[60] Velasco, A. (1987) Financial Crises and Balance of Payment Crises. Journal of Development Economics, 27, 263-283. https://doi.org/10.1016/0304-3878(87)90018-6

[61] Varotsis, N., Katerelos, I. and Ladias, C.A. (2017) Systemdynamik einer steuerreform: Der FallL Griechenland. Zeitschrift für die Regionale Wissenschaft, 8, 29-44.

[62] Organization for Economic Co-Operation and Development (OECD) (2018) Mapping of Investment Promotion Agencies in OECD Countries. IDB, OECD, Paris.

[63] Haavelmo, T. (1960) A Study in the Theory of Investments. The University of Chicago Press, Chicago, IL. 